\title{
Societal, Culture and Entrepreneurial Opportunities Exploitation of New Venture Activities: Mediating Role of Proactiveness
}

\author{
Wang Xuhui \\ Professor and Associate Dean in School of Business Administration, Dongbei University of \\ Finance and Economics, Dalian, China \\ Jia Liu \\ Professor, Dongbei University of Finance and Economics, Dalian, China \\ Frida Pacho \\ PhD student, Dongbei University of Finance and Economics, Dalian, China \\ E-mail: fridaphd@yahoo.com
}

\author{
Received: July 20, $2018 \quad$ Accepted: September 8, $2018 \quad$ Published: October 11, 2018 \\ doi:10.5296/ijrd.v5i2.13762 URL: http://dx.doi.org/10.5296/ijrd.v5i2.13762
}

\begin{abstract}
An unanswered question is concerned with the influence of culture of individualism, power distance and uncertainty avoidance in entrepreneurs' opportunity exploitation of new venture activities in developing economies in the context of societal level. Based on the sample of 130 individual entrepreneurs in Tanzania, this paper analyses how culture of individualism, uncertainty avoidance and power distance influence entrepreneurial opportunity exploitation of new venture activities on societal level. The results indicated that the culture of individualism contributes highly on entrepreneurs' opportunity exploitation of new venture activities. The results of uncertainty avoidance imply that the greater the uncertainty avoidance, the less the entrepreneurs' chance to exploit opportunities of new venture activities. The proactive behaviour that was used as a mediator variable also contributes to the relationship between individualism, uncertainty avoidance and entrepreneurs' opportunity exploitation of new venture activities. The study has made a contribution to the developing countries literature by focusing on individual entrepreneurs on societal level.
\end{abstract}

Keywords: culture, opportunity exploitation, new venture activities, proactiveness, Tanzania 


\section{Introduction}

Because entrepreneurs mature within a societal context, their behaviour and attitude toward venture creation and processing are likely to be influenced by the underlying value of their society values such as culture. Recent literature has proved that culture is positively related to entrepreneurship. Well-constructed culture has been observed in the literature as one of the reasons for entrepreneurs to respond (exploit) to opportunities (Berger, 1991). Logically, culture is said to play a big role in influencing the entrepreneurs' behaviour to act on opportunities. Former authors associated culture in general with the behaviour of entrepreneurs. For example, (Contiua et al., 2012, Baughn and Neupert, 2003) studied culture and ability to influence students' entrepreneurial spirit. Culture and national conditions facilitate start-up of new venture. Mueller and Thomas (2001) including culture and entrepreneurial potential (to mention few of them). In addition to that, literature suggests that there is a strong relationship between cultural environment and entrepreneurs' essential characteristics to involve themselves in entrepreneurial process (Tang, 2008, Hansen et al., 2011).Thus the previous studies have witnessed the relationship which culture has with entrepreneurs to act on opportunities such as starting a new venture and entrepreneurial process. Despite the fact that there are few literatures specifically those which examined the relationship of culture of individualism, uncertainty avoidance and power distance on opportunity exploitation such as start-up activities in developing countries, the contribution of culture to influence entrepreneurship has recently suggested that people who identified themselves with two or more cultures have been contributing to economic development such as opportunity exploitation by opening new ventures (Dheer and Lenartowicz, 2016). This fact provided the gap to assess this relationship in the developing countries. Most of these studies have investigated how the overall country's culture influences entrepreneurship in developed economies but the assessment of culture (individualism, uncertainty avoidance and power distance) of individual entrepreneur to act on opportunities have been neglected in developing countries.

The current study makes two contributions; first it develops from theory and empirically validates a model that links three culture dimensions to the degree of entrepreneurial opportunity exploitation in new venture activities. The novelty of this is that the study is assessing this relationship in Tanzania's new venture activities. There is an interesting story about the country of interest that; before market system and during colonialism era, Tanzania adopted socialism policy which banned its citizens to participate in business activities (Katundu \& Gabagambi, 2014). This system was embedded in socialism culture of highly collectivism, highly power distance and highly uncertainty avoidance (Garcia et al., 2014). As the country's economic policy changed to market system where the national enterprises were privatised, entrepreneurship started being promoted in schools and through World Bank aid programmes. It has been observed that there is no empirical study associated with culture of individualism, power distance and uncertainty avoidance to influence entrepreneur to act on an opportunity after change of the economic system. Furthermore, we mediate the relationship using the proactiveness behaviour of entrepreneurs to explain more of observed behaviour (JR et al., 2009). 
Second; the study uses survey data from Tanzania, an African country. This African setting with a developing economy context adds insight into theories that have been developed mostly in developed economies by reflecting on Tanzania entrepreneurs' new venture context. This is to provide the first impression on the role of culture at individual level to find out societal culture configuration in the country. Hofstede's national level cultural dimensions are conceptually and empirically somewhat different from individual culture value as conceptualized and measured by others because all citizens of the country may not share similar cultural characteristics (Sharma, 2010). Thus, culture heterogeneity that may exist in the one society is ignored. This fact has also been revealed in Hofstede's studies whereby Africa countries have been combined as one country. Therefore, this study used Hofstede's culture theory to provide detailed culture information, but assessed the culture dimensions by adopting the appropriate measurements developed by (Yoo et al., 2011, Sharma, 2010)for measuring of individual cultural orientation.

The empirical results of our empirical study suggested that culture contributes significantly to the entrepreneurs' opportunity exploitation with individualism appearing positively and significantly influencing entrepreneurs 'opportunities exploitation of new venture activities. By using the proactiveness as a mediator to test the relationship, the individualism was full mediated. Moreover, uncertainty avoidance appeared to negatively contribute to entrepreneurs' opportunities exploitation. Therefore, it is believed that the greater the uncertainty avoidance, the less the influence of exploiting opportunities of new venture activities. By using the proactiveness as a mediator, the uncertainty avoidance was partially mediated in the relationship. We managed to score these results using Structural Equation Model approach (SEM) the method which allows to scrutiny the details of each dimension simultaneously (JR et al., 2009).

Nevertheless, we found insignificant relationship between power distance and entrepreneurs' opportunities exploitation the result of which was expected given the nature of the area where the data were collected. Thus, highly power distance does not influence the entrepreneurs to exploit, with or without entrepreneur's behaviour. Uncertainty avoidance result depicted that an increase of it hinders entrepreneurs to exploit opportunities This kind of behaviour and the results of exploitation is likely in countries with low level of technology and high level of economic risks (Kreiser et al., 2001).

\section{Literature Review}

Our study based on the influence of culture in entrepreneurial opportunity exploitation of new venture activities although it lacks the specific theory which connects culture and entrepreneurship. This study decided to use Hofstede theory (Hofstede, 1980, Hofstede, 1984) to determine the culture details to some extent. The theory does not explain the relationship between culture and entrepreneurship, but it gives a highlight on the behaviour of people who belong to different nations. Furthermore, it made the contribution to the entrepreneurship by explaining that countries differ in individualism, uncertainty avoidance and power distance, which these components are related to the wealth and economic development of societies (Hofstede, 1980).This statement further connects Hofstede's culture theory and 
entrepreneurship due to the fact that the entrepreneurship meant for economic development of a country (Luo and Junkunc, 2008, Schumpeter, 1934b). This study was guided by the suggestion made by (JR et al., 2009) that theory can come from prior empirical research or past experience and observations of actual behaviour, attitude and other phenomenena. Therefore, our study theory relied on prior different studies to communicate the relationship of culture in entrepreneur opportunity exploitation of new venture's activities.

\subsection{Construct of Culture in Entrepreneurship}

Before assessing the correlation between culture and entrepreneur to exploit opportunity such as new venture activities, it is crucial to scrutiny in the literature the relationship regarding culture and entrepreneurship. This validated the relationship examined due to the fact that there is no specific theory which connects this relationship. Literature proved that entrepreneurs are embedded in the environment which they are in. The study by (Davidsson and Wiklund, 1997) suggested that the relationship between culture and entrepreneurship in new venture activities occurs perhaps due to the following reasons: first, having large pool of potential entrepreneurs in the region. These are those individuals with value and belief about start up activities. Second, value and beliefs among others in an individual's environment may be the cause of that individual to go into start up firm activities or not. Apart from culture, other environmental factors such as social (Tocher et al., 2015, Baron and Markman, 2000) and political system (Luo and Junkunc, 2008) have been associated with influencing entrepreneurship. However, the current study put its attention on culture. Culture has been defined as an underlying system of values peculiar to a specific group or society that shapes the development of certain personality traits and motivates individuals in a society to engage in behaviour that may not be evident in other societies (Hofstede, 1980, Mueller and Thomas, 2001). Culture of individualism, power distance and uncertainty avoidance have been given attention in the literature such as by (Engelen et al., 2015, Kreiser et al., 2001, Hayton and Cacciotti, 2013, Hayton et al., 2002, Valliere, 2014, Fortunato and Alter, 2016, Mihet, 2012, Mueller and Thomas, 2001) who have done studies among different nations.

However, the culture dimensions of Hofstede are most widely accepted among entrepreneurship scholars (Marino et al., 2002). The culture of uncertainty avoidance describes the level of the degree to which individuals dislike unstructured, ambiguous and uncertainty situations. The culture of individualism (vs collectivism) describes the degree to which an individual belongs to a group or individuals. The culture of power distance captures the degree to which people accept that power is unequally distributed (Hofstede and Hofstede, 2001).

Recent research reveals the benefits of looking at the culture dimensions and entrepreneurial activities (Engelen et al., 2015, Fortunato and Alter, 2016, Mueller and Thomas, 2001, Hayton and Cacciotti, 2013, Kreiser et al., 2010b, Kreiser et al., 2001). As a logical extension of extant, research theorists have posited possible combination of culture on entrepreneur's new venture activities. For example, the study by Mueller \& Thomas, (2001) found that culture of individualistic and uncertainty avoidance influence entrepreneurs' locus of control and innovation in new venture formation. However, this study examined cross-cultural 
society only in western countries. Thus, if an entrepreneur adopted internal locus of control or innovation, these qualities would provide him/her with abilities to work on a new venture activities. The study by (Kreiser et al., 2010b) assessed the relationship between national culture (individualism, power distance, uncertainty avoidance and masculinity) which uncertainty avoidance and power distance had significant negative effect on proactive behaviour of entrepreneur. This study assessed culture in six countries in Europe and Asia. In contrast, the study by (Engelen et al., 2015) assessed the culture of individualism in entrepreneurial orientation in nine countries in US, Europe and China. On its part, the study by Taylor \& Wilson, (2012) indicated that the culture of individualism has an impact on innovation behaviour of entrepreneurs of which uncertainty avoidance resulted into negative association with innovation (Shane, 1993). By assessing literature, first, majority of literature accessed the relationship of culture in entrepreneurship in developed economies while developing economies were ignored. Second, most studies conceptualized and measured Hofstede's national cultural dimensions which is different from individual cultural values because people of a country may not share similar cultural characteristics (Sharma, 2010).

To this end, we extend our search in developing countries in Africa. On this regard, fewer studies have been done in low economies countries such as Tanzania which therefore, this study aimed to give attention to. This study borrows the literature of culture and its capability to influence entrepreneurs from western studies due to the fact that the literature regarding this aspect is scanty if not available. Consideration of examining the influence of culture in entrepreneurs to deal with exploitation of new venture activities is crucial to emerging economies because first, emerging economies depend on entrepreneurship (Lee and Peterson, 2000, Adebayo et al., 2011). This statement is supported by the fact that policy makers of these countries have seen entrepreneurship as the means of stimulating economic growth and job creation (Stephan and Pathak, 2016, Zahra, 1999, Schumpeter, 1934a).However, construction of well dependent culture which can influences entrepreneurs to act on opportunities has been a challenge. Second, African countries are in historical process of transformation in which culture, society and economy are changing from pre-industrial to industrial (Kragh, 2016, OECD, 2007). Pre-industrial norms are said to be qualitatively different from principles which govern entrepreneur's and way of operating venture in Africa compared to the way industrialized world are conducting business (Kragh, 2016). African people are believed to be embedded on the culture of high uncertainty avoidance and power distance (Gardiner, 1996) and high in collectivism (Nyambegera, 2002, Swartz and Davies, 1997). This kind of culture h left Africa in growth stagnation and persistent conflict for the past fifty years whereas the remaining world was experiencing a wide diversity of economic development(Naudé, 2013, Naudé et al., 2011). Despite all these facts, entrepreneurship has remained a solution to economic woes in African countries. Existing literature provides another evidence that, despite the unfavourable culture imbedded in many African countries' low economies(with low GDP) entrepreneurs can be as creative as of those from high economies (Clydesdale, 2010, Mwasalwiba et al., 2012). However, very few studies have given attention to these three variables in explaining the relationship in the area. Therefore, understanding what aspects of culture are relevant for individual entrepreneurship and how or through which mechanism they operate, can help to conceptualize 
entrepreneurship theories (Stephan and Pathak, 2016) remain crucial. This includes the ability to notice, pick, process, interpret and finally use the refined data to take action in the very uncertainty world and exploit market opportunities (Ferrante, 2005) A study related to culture of individualism, power distance and uncertainty avoidance in entrepreneurship in Africa is that by (Yeboah, 2014) which looked at the influence of culture dimensions in entrepreneurs' risk taking behaviour which showed positive association of power distance and individualism on risk taking behaviour. The study by (Mkasanga, 2015) investigated the influence of culture's dimensions (masculinity, uncertainty avoidance and collectivism) on business initiatives on women in Tanzania. Its results indicated that culture influences women to take business initiatives. Again, the study by (Hellsing and Olsson, 2010) investigated the level of entrepreneurship between women in Tanzania compared to women in Norway. This study regarded women as embedded in collectivism culture in Tanzania while the women in Norway were embedded in individualism culture. The results indicated that women in these different cultural backgrounds were experiencing a different situation. This study (Hellsing and Olsson, 2010) used only six observations to draw conclusion and therefore is not reliable to draw conclusion about the culture in Tanzania.

The newness of measuring the influence of culture of individualism, uncertainty avoidance and power distance in entrepreneurs' to exploiting opportunities such as new venture activities in the area of interest (Tanzania) has been caused by some facts analysed in the literature. These facts expressed that: during colonialism there was a policy implemented to prevent citizens from participating in business activities especially during the 1960s (Katundu \& Gabagambi, 2014). However, after the country gained its independence, it adopted socialist policy which also prevented her citizens from participating in business activities which had a nature of capitalism which was regarded as an economy's enemy (Chiraka, 2012). Socialism as a policy failed in 1980 where the country ended up in economic crisis which forced the government to restructure its economic fabric and therefore started implementing privatization policy where market system was adopted resulting in privatisation of majority of the national enterprises. Forthwith, the policy started promoting foreign investment and local entrepreneurship (Katundu \& Gabagambi, 2014). Nevertheless, the history of how Tanzania citizens adopted entrepreneurship was not the focus of this study and therefore, the subject was highlighted in passing.

\section{Hypothesis Development}

\subsection{Culture and Opportunities Exploitation}

The purpose of this study was to deal with the informal institution (culture) that we believe if it is well constructed it can be the source of entrepreneurial behaviour to make a move to opportunities exploitation such as new venture activities. The literature revealed that, for entrepreneurs to act on opportunity exploitation, it depends on their culture surroundings. Few studies correlate culture and opportunity exploitation of new venture activities. For example, most of the entrepreneur's opportunity studies (Corbett, 2005, Corbett, 2007, Prandelli et al., 2016, Riquelme, 2013, Endres and Woods, 2006, Wood et al., 2016, Wood et al., 2014) have only addressed opportunity exploration and exploitation potentially 
existing for entrepreneurs but without considering the environment they are in. However, some studies have suggested culture influences entrepreneurs to act opportunity exploitation such as the new venture activities. A study by (McGrath et al., 1992) found that values held by individuals in taking initiative of opening their own business were related to the four dimensions identified by Hofstede. The study by(De Clercq et al., 2013) investigated opportunities exploitation by a number of new business activities where it involved culture as a moderator variable. Again, the study by (Mueller and Thomas, 2001) assessed how national culture and national conditions facilitate start-up of new venture. The study of Mueller aligned with the study by(Thornton et al., 2011) in suggesting that the environment surrounding may be a formation of different cultural values in different societies which some of them might be the source of entrepreneurs to build a new business. Another study by (Baughn and Neupert, 2003) suggested that culture shapes institutional practices and policies therefore facilitating or constraining the formation of new start up. What is common in most of these studies is that they are oriented to the concept national culture which suggests that citizens of a given country share similar cultural characteristics, the idea which is against the current study. Therefore, basing on the theory addressed in the literature, we suggested the following hypothesis:

H1. Culture can positively influence entrepreneurs 'opportunity exploitation of new venture's activities.

\subsection{Dimensions of Culture and Entrepreneurial Opportunity Exploitation}

By definition, individualism, is the condition where the individual has an independent self-construal, where a high value is placed on personal autonomy and individual initiative and greater importance is given to personal interests than that of the group (Hofstede, 1980). Thus, the culture of individualism (vs collectivism) describes the degree to which an individual belongs to a group or on one's own. Successful entrepreneurs are explained to be self-motivated, creative, willing to act independently(Abraham, 1997). Thus, the high level of individualism results in high level of entrepreneurship. Based on the literature, individualism is claimed to have a relationship with entrepreneurial orientation (Mueller and Thomas, 2001, Lee and Peterson, 2000). To connect the relationship between individualism and entrepreneurs' response to opportunity exploitation, the study by (Tiessen, 1997) suggested that an individualist shows tendencies for new formation and makes major innovations. Thus, entrepreneurs who own new venture always aim to generate a variety through innovation and establishing external ties. Therefore, individualism is one of the culture instruments in different functions of entrepreneurs. The study by(Mitchell et al., 2000) which assessed cross-cultural cognition found that individualism is associated with willingness, ability script and with the venture creation decision. Thus we suggested the following hypothesis:

H2. The culture of individualism can positively influence entrepreneurs' opportunity exploitation of new venture activities.

Uncertainty avoidance refers to the extent to which the members of a culture feel threatened by uncertain or unknown situations (Franke et al., 1991). The level of uncertainty avoidance in the society can shape the behaviour of entrepreneurs to act on opportunities. In the study 
by (McGrath et al., 1992, McGrath and MacMillan, 2000) it was suggested that in industries that face increasingly uncertainties, the demand of entrepreneur can also increase because of their ability to operate in highly unpredictable and competitive situations. The study by (Mitchell et al., 2000) which assessed cross-cultural cognition found that uncertainty avoidance was associated with willingness, ability script and with the venture creation decision. Again, the study by Kreiser et al., (2010b) revealed that entrepreneurs in society with a low level of uncertainty avoidance are likely to involve into opportunity exploitation than a high level of uncertainty avoidance. Members of some societies that tend to be anxious about the unpredictability of the future will have implication for innovation and entrepreneurial activities in that country (Shane, 1995). These studies however have mixed findings that in low uncertainty avoidance culture, entrepreneurs are believed to have a greater tolerance for novel behaviour which may cause them to deviate from social norms (Baughn and Neupert, 2003). However, the study by Carson et al., (2014) found that during uncertainties, individual find it safe to adjust with the environment rather than remain inflexible. Basing on these studies therefore, this study suggested the following hypothesis:

H3. The culture of uncertainty avoidance can negatively influence entrepreneurs' opportunity exploitation of new venture activities.

Power distance refers to the extent to which people believe and accept that power and status are distributed unequally (Franke et al., 1991, House et al., 2002). The society with a high level of power distance value is likely to reduce individuals' morale to act on opportunities (Engelen, Schmidt et al. 2015). The study by(Kreiser et al., 2010a) supported that firms' behaviours are negatively associated with the level of power distance in a culture. It is believed that high power distance countries tend to distribute resources unequally. These resources are an impact factor on venture building. Based on that, entrepreneurs who have no power fail to take advantage of potential opportunities available and as result, they face some difficulty in attaining resources, skills and information (Zhao et al., 2012). Individuals in a culture of high power distance culture have less freedom to make bold decision (Thompson, 1967). By these arguments and intuition that entrepreneurs in their venture prefer low power distance culture to aggressively implementing their day to day strategies, it is expected that low power distance culture will influence entrepreneurial opportunity exploitation hence our hypothesis that

H4. The culture of power distance can negatively influence entrepreneurs' opportunity exploitation of new venture activities.

\subsection{Entrepreneurial Proactiveness as a Mediator}

The following hypotheses gave a thought on how individual's proactive behaviour can be a reason for entrepreneurs to involve themselves in opportunity exploitation of new venture activities. New and ongoing venture's opportunities exploitation depends on their environment which in turn gives birth to the behaviour of entrepreneurs. The proactive behaviour of an entrepreneur is defined as behaviour on which an individual is relatively unconstrained by situational forces and he is the one who effects environmental change. Individuals with proactive personalities identify opportunities and act on them, show 
initiative, take action and persevere until they bring about meaningful change (Bateman and Crant, 1993). This study picked entrepreneur proactiveness as mediator variable by the fact that, the way a firm or individual approach and management effort on exploitation are, is determined by their behaviour. To give a detailed thought on proactiveness, studies expressed it as, to find a new way to grow, to set effective and change oriented goals, anticipate and prevent problems, do it in different fashions, action oriented, persevere and achieve results (Bateman and Crant, 1993, Crant, 2000, McGrath et al., 1992).In addition to that, Lumpkin and Dess explained proactiveness as an opportunistic act for the purpose of shaping environment through influencing trend and generating demand with the aim of becoming the first mover in the market. From opportunities point of view, proactiveness suggests that one is expecting potential opportunities and is prepared to take them when they appear (Frese, 2009). It is the kind of behaviour that impacts the environment(Crant, 1996). Proactiveness attributes have been seen to impact levels of entrepreneurship especially in taking actions. The evidence for mediating processes linking culture and behaviour remains sparse and inconsistent, often dogged by methodological challenges (Hayton and Cacciotti, 2013).As it is believed, effective culture with low power distance, low uncertainty avoidance and high individualism (Hansen et al., 2011) is effective to entrepreneurs who are said to be a source of opportunities exploitation. Therefore, fostering entrepreneurial proactive behaviour is expected to be conducive to successful opportunity exploitation. By considering all these thoughts, we suggest that:

H5-i Entrepreneurial proactive behaviour mediates positively the culture of uncertainty avoidance and opportunities exploitation of new venture activities

H5-ii Entrepreneurial proactive behaviour mediates positively the culture of individualism and opportunities exploitation of new venture activities

H5-iii Entrepreneurial proactive behaviour mediates positively the culture of power distance and opportunity exploitation of new venture activities.

\section{Methodology}

\subsection{Research Design}

The philosophy applied in the study is post-positivism whose basic principle claims that the researchers cannot be completely certain about the knowledge they claim about the behaviour action of human being(Clark, 1998). This declaration is confirmed by constant modification of existing theories which are available that can confirm new reality. This study is relevant to the mentioned philosophy due to the fact that, it treats culture as an antecedent and opportunities exploitation of new venture activities as an outcome.

\subsection{Data Collection and Sample}

In this study, the proposed model was tested using quantitative methods whereby survey data were used. We scanned data from Tanzania National Bureau of Statistics and Business Registration and Licencing Agency. Population includes different types of individual entrepreneurs with new ventures with the business which started from at least 3 years ago 
(Castles, 1997). These ventures were in different industries including wholesaling and retailing business, Agro processing, Tourism, ICT and renewable energy service providers. The survey period was four months. We got demographic makeup of the sample including 60 $(46.2 \%)$ women and $70(53.8 \%)$ men. The average age was $34.15(\mathrm{SD}=8.584)$ and experience of 3.2years. We used Levene's test (t-test) to find out whether there was difference between female and male entrepreneurs where the results indicated that there was no significant differences between men and women (above 0.05). The survey instruments employed were developed in the English language at first but underwent translation process. Tanzania is using English and Kiswahili as formal languages however the majority of her people speak Swahili in their daily operations So Swahili is regarded as the appropriate language to use in all types of entrepreneurs. However, the Kiswahili version of the questionnaire was translated again into English by an independent scholar for the purpose of assessing if the two versions were conceptually as well as linguistically equivalent where as a result, few errors were observed and corrected.

\subsection{Variables and Measurement}

The aim of the study was to measure and assess the relationship between independent (exogenous), mediating (indigenous) and dependent (indigenous) variables as follows:

\subsubsection{Dependent Variables}

Opportunities exploitation was measured by means of multiple items which relied on existing measurements scales that have been validated in the literature. Three items consistent with an opportunity exploitative of new activities such as "My venture is establishing a new business" "My venture is finding new niche in a current market" "My venture is financing currently work on start-up activities". The measures were on a7-point Likert scale ranging from 1(strongly disagree) to 7(strongly agree). The scale was adopted from (Simsek and Heavey, 2011, Zahra, 1996, Simsek, 2007). This scale is useful for start-up activities for the purpose of adapting to current environment conditions to the needs on the new venture achievement requirements. Previous research highlights the usefulness of such subjective measures since they display strong reliability and validity and are also particularly useful for assessing wider non-financial dimensions of performance(Dess and Robinson, 1984, Chandler and Hanks, 1993).

\subsubsection{Mediating Variables}

Entrepreneurial proactive behaviour measurement is based on 3 items (Likert scale ranging from 1 = strongly disagree to $5=$ strongly agree for each item stemming from Lumpkin and Dess. (Lumpkin and Dess, 1996b, Covin and Slevin, 1991) On the view of proactiveness as behaviour of new techniques in competitive environment it was suggested to be applied for the purpose of testing entrepreneurial orientation in different environments (Kollmann et al., 2007)In the survey, the respondents were asked to report their level of proactiveness with questions i.e."I usually act positively on dynamic environments such as future problems, needs and changes", "I tend to plan ahead on projects" and "I prefer to step-up and get things done on projects rather than sit and wait for someone else to do it". 


\section{Mll Macrothink}

There are some changes made to catch up with individual entrepreneurs whose ventures are still at initial stage. This dimension was also tested and validated by (Taatila et al., 2012, Langkamp Bolton and Lane, 2012) at the individual level of entrepreneur which claimed that the measurement instruments are useful to individuals who want to assess the strength of their orientation toward entrepreneurship.

\subsubsection{Independent Variables}

By using (Yoo et al., 2011, Sharma, 2010)construct for measuring individual culture values, 5 items measured power distance( example "People in lower positions should not disagree with decisions by people in higher position"), 4 items measured uncertainty avoidance ( i.e. "it is important to have instructions spelled out in detail so that I always know what I am expected to do"), which had one item deleted because it failed to meet face validity requirements. 5 items measured individualism ("I would rather depend on myself than others"), in which also one item was deleted as it failed to meet face validity requirements-. All variables tested using 7-point Likert scale from 1: strongly disagree to 7: strongly agree. The dimensions scale was also re-measured and re-validated b (Mazanec et al., 2015) and proved to be reasonable and reliable means of measuring culture at the societal level. And it was used in Thailand by (Prasongsukarn, 2009) which again exhibited suitable reliability and validity to be used in Thailand for the reason of cultural assessment at the individual level.

\subsubsection{Control Variables}

We controlled the effect of four covariates that were believed to influence the outcome predicted. The prior studies suggested demographic variables such as age, experience, education and gender to have a direct impact on the one to decide on activities (Altinay and Wang, 2011, Chang et al., 2012, Gielnik et al., 2012, Gupta et al., 2014).

\subsection{Theoretical Model}

First, the model predicted a direct relationship between culture and entrepreneurial opportunities exploitation. With the suggestion that the construct and dimension level effect of culture enhance the likelihood of entrepreneurs to exploit opportunities. Secondly, it depicts that the culture is an antecedent of entrepreneurial proactive behaviour. The dotted line box means a construct level effect of the culture that originated from the three sub-dimensions. The arrows which point to each dimension depicts that the dimensions through each have a distinct role determine the effect of culture collectively. Then hypothesis section offerings further theoretical support regarding the causal relationship between culture and proactiveness. Lastly, it proposes mediation effect of proactiveness behaviour. 


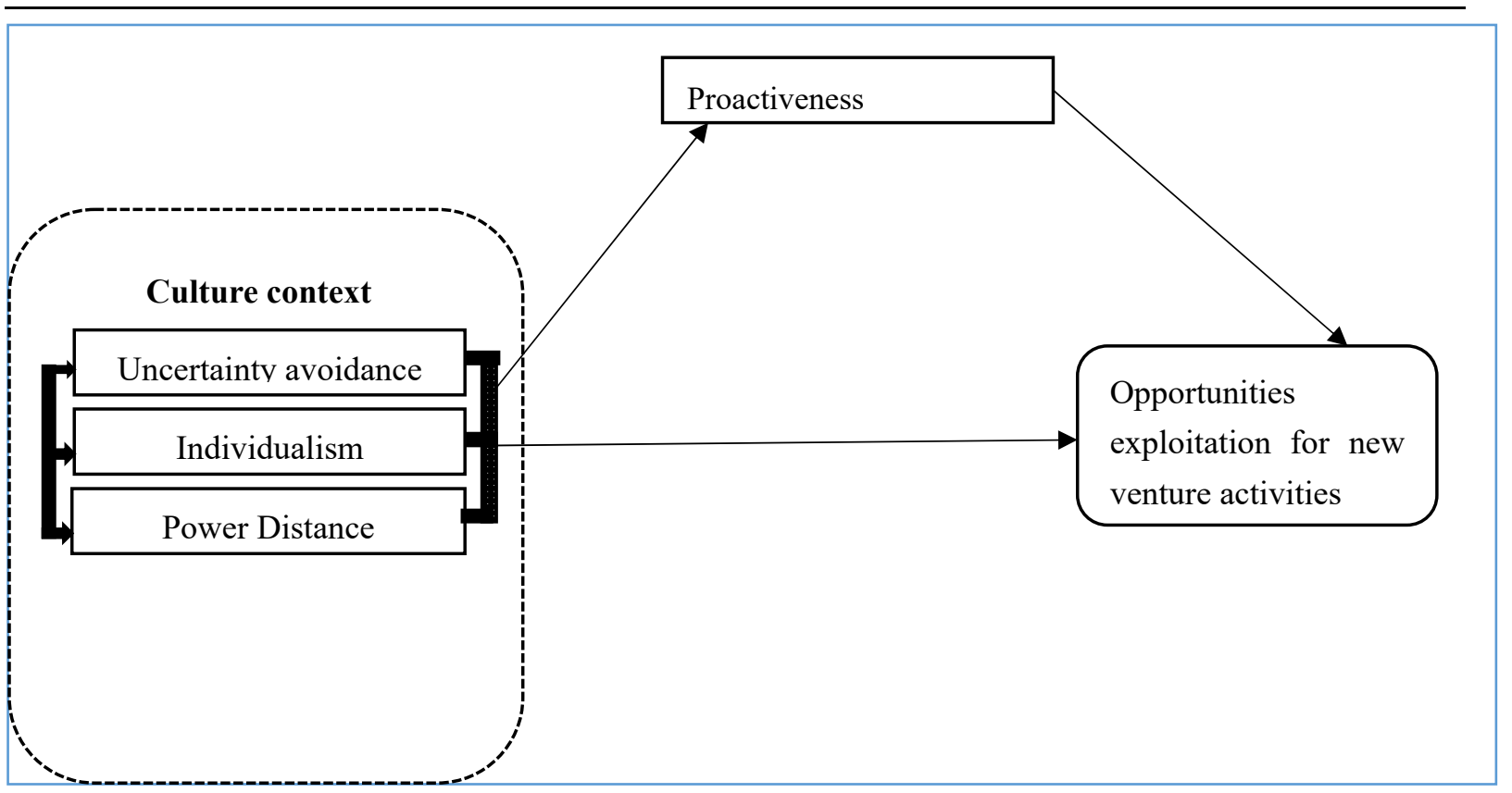

Figure 1. Conceptual framework of the study

\section{Results}

The results of this study are presented by first presenting non-violation of assumptions of multicollinearity, normality, singularity and outliers then followed by descriptive statistics. Lastly, they convey the results for hypothesized relationship. As we examined multicollinearity, we considered the assumption that when the correlation between two or more independent variables is 0.7 or above $(r \leq 0.7)$ it suggests the existence of multicollinearity. Multicollinearity concerns are when the predictor's variables are highly correlated with themselves which as a result, it might affect the explanatory power in predicting the score of the outcome variables (Pallant, 2007). We also examined VIF for multicollinearity and singularity where tolerance indicated how much variability for predictor variable is not accounted by another predictor variable, small VIF is desirable and greater than 10 suggests there is multicollinearity concern. Our VIF ranged between 1.00 and 1.26 for culture, uncertainty avoidance, individualism and power distance were all below the cut-off score as required. The correlation coefficients also indicated that the variables correlated as required among themselves $(0.023 \leq \mathrm{r} \leq 0.50)$.

\subsection{Descriptive Analysis}

The reason for Table 1.0 is to present the descriptive statistics for the predictor variables, outcome variables and controls. The sample consists of $60(46.2 \%)$ women and $70(53.8 \%)$ men with the average age of $34.15(\mathrm{SD}=8.584)$ and experience of 3.2 years for both sexes. Consistent with the proposed hypotheses, the culture variable related positively with the opportunities exploitation at both construct and dimensional level. Similarly, the culture positively related to proactiveness. However, these variables related with each other only modestly as indicated by the correlation coefficient with variations from 0.013 to 0.59 which indicates that the relationship is somehow not so strong to raise multicollinearity concern(Hoyle, 2012). 
Table 1. Correlation, Means and Standard Deviations

\begin{tabular}{|c|c|c|c|c|c|c|c|c|c|c|c|}
\hline & Variables & 1 & 2 & 3 & 4 & 5 & 6 & 7 & 8 & 9 & 10 \\
\hline 1 & $\begin{array}{l}\text { Entrepreneurs } \\
\text { 'Age }\end{array}$ & & & & & & & & & & \\
\hline 2 & Experience & 0.432 & & & & & & & & & \\
\hline 3 & Education level & 0.086 & 0.010 & & & & & & & & \\
\hline 4 & $\begin{array}{l}\text { Uncertainty } \\
\text { avoidance }\end{array}$ & 0.153 & 0.019 & 0.021 & 0.709 & & & & & & \\
\hline 5 & Individualism & $0.208^{*}$ & 0.127 & 0.080 & $0.496^{* *}$ & 0.808 & & & & & \\
\hline 6 & Power distance & 0.109 & 0.121 & 0.023 & $0.387 * *$ & $0.251 * *$ & 0.714 & & & & \\
\hline 7 & Culture & $0.207^{*}$ & 0.100 & 0.019 & $0.580 * *$ & $0.590 * *$ & $0.490 * *$ & & & & \\
\hline 8 & Proactiveness & 0.041 & 0.162 & 0.026 & $0.324 * *$ & $0.474 * *$ & $0.210^{*}$ & $0.447 * *$ & 0.823 & & \\
\hline 9 & $\begin{array}{l}\text { Opportunity } \\
\text { Exploit }\end{array}$ & 0.039 & 0.113 & 0.053 & $0.241 * *$ & $0.212 * *$ & $0.221 *$ & $0.161 *$ & $0.301 * *$ & & \\
\hline \multirow[t]{3}{*}{10} & Gender & 0.155 & 0.101 & 0.024 & 0.036 & 0.007 & 0.087 & 0.091 & 0.135 & 0.718 & \\
\hline & Mean & 34.15 & 5.21 & 4.44 & 4.50 & 5.08 & 3.65 & 4.41 & 3.99 & 3.36 & 0.74 \\
\hline & SD & 8.58 & 4.85 & 0.807 & 1.57 & 1.69 & 1.46 & 1.21 & 0.99 & 0.743 & 0.441 \\
\hline
\end{tabular}

$\mathrm{N}=130 * \mathrm{P} \leq 0.05, * * \mathrm{P} \leq 0.01$ 2-tailed (The numbers in boldface indicate the square root of the AVE. There is no correlation which is greater than the corresponding $\sqrt{ }$ AVE)

\subsection{Measurement validation (Discriminant, Convergent, Nomological and Face Validity)}

First, we started by checking the goodness of fit (GOF) of overall measurements as follows: we checked goodness of fit using chi-square which compares the estimated and observed covariance matrices. Our chi-square value was 275.774 with $\mathrm{df}=160$ significance. Thus, the chi-square in this study does not indicate that the observed covariance matrix matches the estimated covariance matrix within sampling variance. But Chi-square explained in the studies as too sensitive to the model complexity and size (JR et al., 2009). Therefore, we examined other fit statistics as well. The absolute fit indices used to measure the overall goodness of fit of the model which we measured GFI $=0.821$ (cut off suggested is 0.90), RMSEA $=0.075$ (cut off suggested RMSEA should be less than 0.08), Normed Chi-square. $=1.725$ (2-5 is acceptable, but a smaller than 2.0 is considered to be very good). With incremental fit indices we checked Comparative Fit Index (CFI) $=0.909$, and Tucker-Lewis Index (TLI) $=0.891$ (Higher values of CFI, TLI indicate a good fit, while lower values indicate a poor fit) (JR et al., 2009). Lastly, we checked the parsimony fit indices which attempt to correct the over-fitting of the model and assesses the parsimony of the hypothesized model relative to the goodness of fit (Kline, 2011). In this study, we checked Adjusted Goodness of Fit Index (AGFI) $=0.766$ and Parsimony Normed Fit Index (PNFI) $=0.683$. Which the higher AGFI and PNFI indicate a goodness of fit and lower indicate a poor fit according to (JR et al., 2009).

Second, construct validity were used to find out if measured variables (items) accurately reflect the theoretical constructs (latent factors) that they are designed to measure(JR et al., 2009). Table 2.0 and figure 2.0 present standardized factor loading estimates for all constructs used in this study. They are all statistically significant and greater than the minimum cut-off of 0.50 which confirmed the convergent validity of the constructs making up the 


\section{Macrothink}

hypothesized model. As convergent validity provides evidence regarding the accuracy of indicators of a specific construct, to be attained, it is vital that multiple indicators of a single construct share a high proportion of variance (Hoyle, 2012, Kline, 2011). Also construct reliability (composite reliability) in this study is greater than 0.7 which is higher than the recommended one as shown in Table 2.0. In studies, recommended construct reliability should be 0.7 or higher. Others recommend that the value between 0.6 and 0.7 can also be acceptable. The Average construct variance also proved to be acceptable as exceeded 0.5 as rule of thumb.

We also checked the nomological and face validity. The face validity was assessed to ensure that the content of the measured items is correct and is well measured in line with the proposed characteristics or attribute. It also checked that the content of each item is unique and does not overlap with other measured items which do not belong to them. On the other hand, nomological validity in forms whether there is logical relationship between the constructs and it makes sense according to the theory.

Whereby, discriminant validity was assessed by calculating the square root of the AVE of each construct. In Table2.0 AVE scores were greater than the cut off value of 0.50 . And as presented, the value of the square root of AVEs along the diagonal on Table 1.0 exceeded the corresponding latent factor correlations in the same row and column. Thus, according to the method, each construct in the hypothesized model was distinct from one another.

Finally, we checked on items' loading pattern so as provide evidence of the discriminant validity of the constructs. There were no cross-loadings of measured items on the latent constructs. Each measured variable well represented single latent factor and not multiple latent factors. These CFA results suggest that the measurement model provides a reasonably good fit and thus it is suitable to proceed for further examinations.

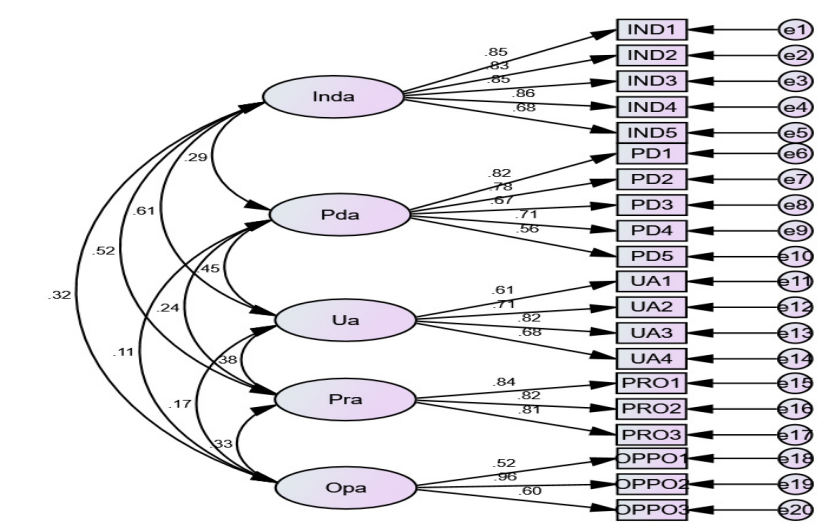

$\mathrm{cmin}=275.774 ; \mathrm{df}=160 ; \mathrm{p}-$ value $=.000 ; \mathrm{gfi}=.821 ; \mathrm{cfi}=.909 ; \mathrm{rmse}=.075$

Figure 2. CFA diagram with standardized loading estimates 
Table 2. Factor loadings, Construct Reliability, Average Variance Extracted scores

\begin{tabular}{|c|c|c|c|c|c|}
\hline $\begin{array}{l}\text { Measured } \\
\text { variables }\end{array}$ & & Construct & $\begin{array}{l}\text { Factor } \\
\text { Loadings }\end{array}$ & $\begin{array}{l}\text { Construct } \\
\text { Reliability(CR) }\end{array}$ & $\begin{array}{l}\text { Average } \\
\text { Variance } \\
\text { Extracted(AVEs) }\end{array}$ \\
\hline IND1 & $<---$ & Indiv & $0.848 * * *$ & & \\
\hline IND2 & $<---$ & Indiv & $0.830 * * *$ & & \\
\hline IND3 & $<---$ & Indiv & $0.851 * * *$ & & \\
\hline IND4 & $<---$ & Indiv & $0.862 * * *$ & & \\
\hline IND5 & $<---$ & Indiv & $0.677 * * *$ & 0.909 & 0.667 \\
\hline PD1 & $<---$ & PowerD & $0.816^{* * *}$ & & \\
\hline PD2 & $<---$ & PowerD & $0.784 * * *$ & & \\
\hline PD3 & $<---$ & PowerD & $0.672 * * *$ & & \\
\hline PD4 & $<---$ & PowerD & $0.709 * * *$ & & \\
\hline PD5 & $<---$ & PowerD & $0.563 * * *$ & 0.837 & 0.51 \\
\hline UA1 & $<---$ & Uncertainty & $0.611 * * *$ & & \\
\hline UA2 & $<---$ & Uncertainty & $0.709 * * *$ & & \\
\hline UA3 & $<---$ & Uncertainty & $0.820 * * *$ & & \\
\hline UA4 & $<---$ & Uncertainty & $0.679 * * *$ & 0.800 & 0.502 \\
\hline PRO1 & $<---$ & Proactiveness & $0.837 * * *$ & & \\
\hline $\mathrm{PRO} 2$ & $<---$ & Proactiveness & $0.818 * * *$ & & \\
\hline PRO3 & $<---$ & Proactiveness & $0.814 * * *$ & 0.863 & 0.677 \\
\hline OPPO1 & $<---$ & Opportexplo & $0.522 * * *$ & & \\
\hline OPPO2 & $<---$ & Opportexplo & $0.958 * * *$ & & \\
\hline OPPO3 & $<---$ & Opportexplo & $0.597 * * *$ & 0.748 & 0.516 \\
\hline
\end{tabular}

Note: $\mathrm{N}=130 * * * \mathrm{p}<0.0001$

\subsection{Direct Effect of Culture Effect on Entrepreneurs' Opportunities Exploitation of New Venture Activities}

Prior the examination of culture on entrepreneurs' opportunities exploitation initiatives we started by looking on whether women or men in the sample differed significantly on their ability to exploit opportunities. We did this because of prior studies found in the society, gender influence ability to opportunity exploitation (Bulanova et al., 2016, Gupta et al., 2014). Therefore, we doubted if there were an alternative factor apart from culture factor we selected, it might distort the findings and the conclusion of our study. Therefore t-test results indicated that no significant difference in the score for male $(\mathrm{M}=3.4236, \mathrm{SD}=0.7453)$ and female $(\mathrm{M}=3.1961, \mathrm{SD}=0.7206) ; \mathrm{t}(130)=1.5, \mathrm{p}=0.13$ (two tailed). The insignificance differences suggest that the entrepreneur's gender was not a concern in the sample which the effect of culture was not reduced by gender. We also checked on the experience, which experienced entrepreneurs $(M=3.3497, S D=0.74456)$ nascent entrepreneurs $(M=3.5833$, SD 0.7291). The insignificant difference in the means suggests the effect of culture was not reduced by the 
entrepreneurs' experience.

\subsection{The Construct-level Effect of Culture}

Sequential regression was used to test the effect of culture on entrepreneurs' opportunities exploitation initiatives at construct level. The results in Table 3.0 reveal that in all models, culture contributed significantly to the entrepreneurs' opportunities exploitation of new venture activities. The model was significant, in the sense that it showed control of culture which accounted for $23 \%$ of the variation in the entrepreneurial initiatives to exploit opportunities $\left(\mathrm{R}^{2}=0.23, \mathrm{~F}=17.34, \mathrm{p} \leq 0.05\right)$.In addition to this, all controls and culture had higher variable tolerance values $(>0.10)$ and VIF scores of less than 10 . These results are the proof of $\mathrm{H} 1$ hypothesis of the study.

Table 3. Sequential regression results on the effect of socio-culture on entrepreneurs' opportunity exploitation of new venture activities at construct level here

\begin{tabular}{|c|c|c|c|c|c|c|c|c|c|c|}
\hline & Variables & $\beta$ & $\mathbf{t}$ & sign & Tolerance & VIF & $\mathbf{R}^{2}$ & $\Delta \mathbf{R}^{2}$ & $\mathbf{F}$ & $\Delta \mathbf{F}$ \\
\hline & Stage 1 & & & & & & & & & \\
\hline 1 & Gender & 0.148 & 1.669 & 0.098 & 0.974 & 1.026 & & & & \\
\hline 2 & Age & 0.013 & 0.137 & 0.891 & 0.795 & 1.259 & & & & \\
\hline 3 & $\begin{array}{l}\text { Entre } \\
\text { Experience }\end{array}$ & 0.123 & 1.258 & 0.211 & 0.811 & 1.232 & & & & \\
\hline 4 & $\begin{array}{l}\text { Education } \\
\text { level }\end{array}$ & 0.152 & -0.047 & 0.558 & 0.991 & 1.009 & & & & \\
\hline & Stage 2 & & & & & & 0.04 & 0.04 & 1.21 & 1.205 \\
\hline 1 & Gender & 0.139 & 1.575 & 0.118 & 0.971 & 1.03 & & & & \\
\hline 2 & Age & 0.048 & 0.48 & 0.632 & 0.769 & 1.3 & & & & \\
\hline 3 & $\begin{array}{l}\text { Entre } \\
\text { Experience }\end{array}$ & 0.124 & 1.289 & 0.200 & 0.811 & 1.232 & & & & \\
\hline 4 & $\begin{array}{l}\text { Education } \\
\text { level }\end{array}$ & -0.058 & -0.667 & 0.506 & 0.99 & 1.01 & & & & \\
\hline 5 & Culture & 1.702 & 1.934 & 0.001 & 0.952 & 1.05 & 0.23 & 0.26 & 17.3 & 37.42 \\
\hline
\end{tabular}

$\mathrm{N}=130 * * * \mathrm{p} \leq 0.001, * \mathrm{p} \leq 0.05$

\subsection{Dimensional Level Effect of Culture}

Table 4.0 depicts the dimension-level of culture on entrepreneurs' opportunity exploitation of new venture activities. Most of the Control variables are an insignificant predictor of opportunity exploitation of new venture activities. Education is negatively a significant predictor of the entrepreneurs' opportunities exploitation. The three dimensions of culture contained different results. Not all three culture dimensions predict their influence on entrepreneur's decision to exploit opportunities. Individualism positively and significantly predicted its influence on entrepreneurs' opportunity exploitation which supported hypothesis 
$2(\beta=0.472, p \leq 0.001)$. Uncertainty avoidance was significant and negatively predicted entrepreneurs' opportunities exploitation $(\beta=-0.342, \mathrm{p} \leq 0.01$, ) which supported hypothesis 3 . Moreover, power distance was insignificant $(\beta=0.116, p=0.219)$ which means hypothesis 4 was not supported. The overall model was significant as controls and culture dimensions explained $30 \%$ of the variation in entrepreneurs' opportunities exploitation decision $\left(\mathrm{R}^{2}=0.30\right.$, $\mathrm{p} \leq 0.05 ; \mathrm{F}=20, \mathrm{p} \leq 0.05)$. Similarly, as it was done in the construct level effect, the tolerance values and VIF scores of the controls and culture were as the cut-off requirements values.

Table 4. Sequential regression results on the effect of socio-culture on entrepreneurs' opportunity exploitation of new venture activities at dimensional level

\begin{tabular}{llllllllll}
\hline Variables & $\boldsymbol{\beta}$ & $\mathbf{t}$ & sign & Tolerance & $\mathbf{V I F}$ & $\mathbf{R}^{\mathbf{2}}$ & $\Delta \mathbf{R}^{\mathbf{2}}$ & $\mathbf{F}$ & $\Delta \mathbf{F}$ \\
\hline Stage 1 & & & & & & & & & \\
Age & 0.013 & 0.137 & 0.891 & 0.795 & 1.259 & & & & \\
Gender & 0.148 & 1.669 & 0.098 & 0.974 & 1.026 & & & & \\
Entre & 0.123 & 1.258 & 0.211 & 0.811 & 1.232 & & & & \\
Experience & & & & & & & & & \\
Education & -0.153 & -0.047 & 0.558 & 0.991 & 1.009 & & & & \\
level & & & & & & & & & \\
Stage 2 & & & & & & 0.037 & 0.04 & 1.2 & 1.21 \\
Age & 0.044 & 0.450 & 0.654 & 0.764 & 1.309 & & & & \\
Gender & 0.125 & 1.429 & 0.155 & 0.961 & 1.040 & & & & \\
Entre & 0.159 & 1.641 & 0.103 & 0.784 & 1.275 & & & & \\
Experience & & & & & & & & & \\
Education & -0.077 & -0.892 & 0.374 & 0.977 & 1.023 & & & & \\
level & & & & & & & & & \\
Uncertainty & -0.342 & -1.345 & 0.010 & 0.659 & 1.516 & & & & \\
Avoidance & & & & & & & & & \\
Individualism & 0.472 & 2.670 & 0.001 & 0.708 & 1.412 & & & \\
Power & 0.216 & 1.235 & 0.219 & 0.830 & 1.205 & 0.30 & 0.11 & 20 & 40.1 \\
distance & & & & & & & & & \\
\hline
\end{tabular}

$\mathrm{N}=130$.

\subsection{Mediation Effect of Culture (Direct-Indirect Relationship)}

The study considered one structural model to define whether the hypothesized mediator mediated fully or partially the relationship between culture and entrepreneurs' opportunity exploitation of new venture activities. The model based on the estimation of indirect effect (direct effect of culture was not estimated here) whereby the culture dimensions were involved. This model was associated to assess the model fit. The model fit was $\mathrm{x}^{2}=55.686$, $\mathrm{x}^{2} / \mathrm{df}=2.53, \mathrm{df}=22, \mathrm{p}=0.414$ with model fit indices $\mathrm{CIF}=0.746, \mathrm{TLI}=0.584, \mathrm{RMR}=2.738$ and $\mathrm{RMSEA}=0.109$. The results for a direct- indirect relationship is as provided in Table5.0 


\section{Ml Macrothink}

Table 5. Mediation results

\begin{tabular}{llll}
\hline Hypotheses & Direct effect & Indirect effect & Results \\
\hline UncA-Proa-OppoE & $-0.253^{* * *}$ & $-0.198^{*}$ & Partial mediation \\
Indiv-Proa-OppoE & $0.472^{*}$ & $0.292(\mathrm{~ns})$ & Full mediation \\
PD-Proa-OppoE & $0.093(\mathrm{~ns})$ & $0.016(\mathrm{~ns})$ & No mediation \\
\hline
\end{tabular}

Ns $=$ non-significant, ${ }^{*} \mathrm{p} \leq 0.05, * * \mathrm{p} \leq 0.01 * * * \mathrm{p} \leq 0.001$.

Uncertainty avoidance was found to be partially mediated because it remained significant (but reduced) after mediation which $\mathrm{H} 5$-i was partially supported. On the other hand, individualism was found to be full mediated because it became insignificant after the mediation variable involved which H5-ii was supported. There was no mediation between power distance and entrepreneurs' opportunities exploitation of new venture activities; therefore, hypothesis 5-iii was not supported. This relationship has been shown in figure 3.0.However; the estimated structural model could not evaluate the significance of the indirect effects. That is, we assessed the significance of indirect effect using bootstrapping analysis. Bootstrapping was accomplished by creating a 95 percent confidence interval (percentile and bias-corrected) around the indirect effect estimates. Consistent with the standard decision criteria, the indirect effect was considered significant when the corresponding confidence intervals excluded zero, otherwise it was regarded as insignificant (MacKinnon et al., 2004).

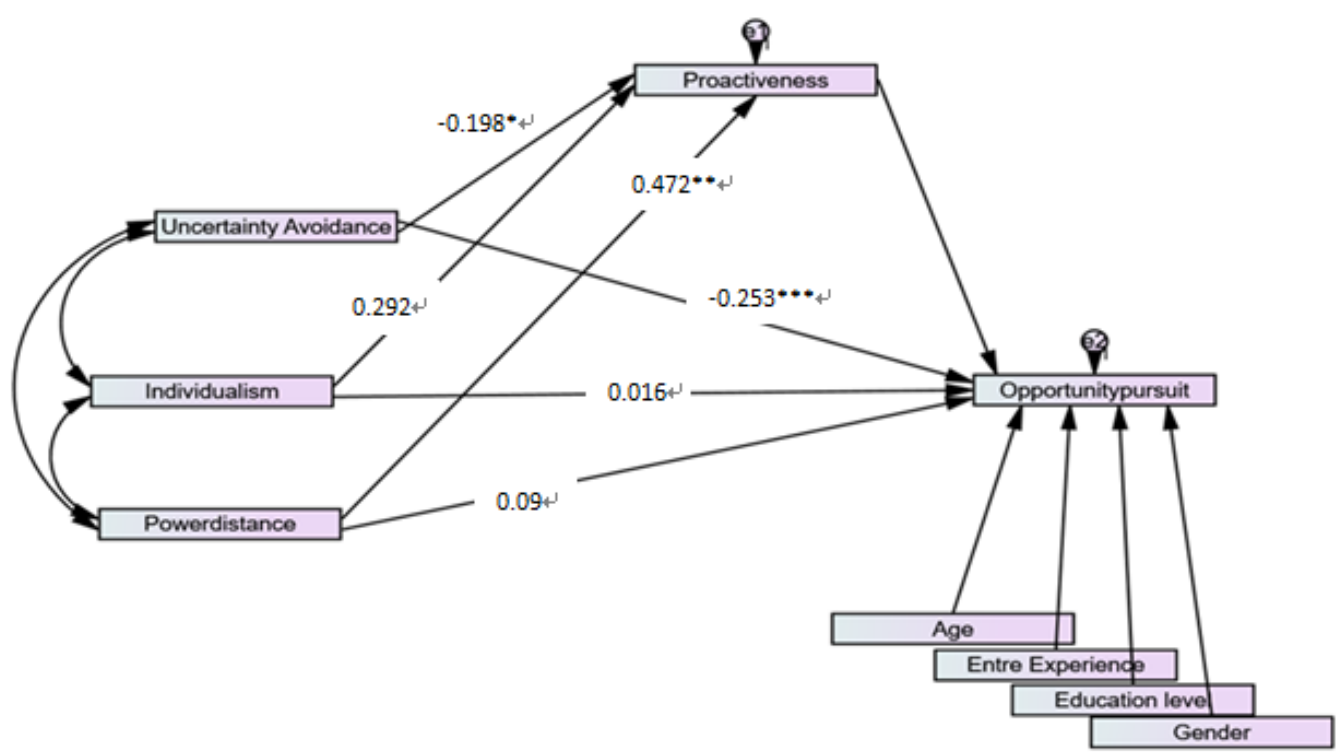

Figure 3. Structural model showing the direct and indirect effect regarding the study

\section{Discussion and Conclusions}

Our study explores the way through which culture influences entrepreneurs' opportunities exploitation of new venture activities in Tanzania entrepreneur. The literature lacks an 
established knowledge of how society culture describes to influence the entrepreneurial opportunity exploitation of new venture activities especially in developing countries. We hypothesized to find out the effect of culture on entrepreneurs' opportunities exploitation by directly considering the effect via entrepreneur behaviour (proactiveness). Previous studies prove that entrepreneurs in a different environment are likely to develop interesting opportunity exploitation (Clydesdale, 2010). Proactive behaviour of entrepreneur has been explained as one of the entrepreneurial behaviours which individual entrepreneurs have (D. Carson et al., 2014, Lumpkin and Dess, 1996a) which helps entrepreneurs to work on opportunities.

Our study results found that culture significantly contributed to the entrepreneurs' opportunities exploitation of new venture activities. Dimensionally, the culture of individualism significantly and positively influenced entrepreneurs' opportunities exploitation of new venture activities, although the relationship tends to drop after the manifestation of the proactive behaviour of entrepreneurs as a mediator. Uncertainty avoidance was negatively attributed to entrepreneurs' opportunities exploitation of new venture activities. Thus, it is true that the greater the uncertainty avoidance the less the participation in exploiting opportunities of new venture activities. These results happened when measured directly and when measured via entrepreneurs 'proactive behaviour as a mediator. Despite this fact, there remains some relationship between uncertainty avoidance and entrepreneurial opportunity exploitation of new venture activities. Nevertheless, the insignificant relationship between power distance and entrepreneurs' opportunities exploitation of new venture activities was anticipated given the nature of the area where the data were collected. Thus the environment where high power distance is exercised, it cannot influence entrepreneurs to exploit opportunities, with or without entrepreneur proactive behaviour. This is due to the fact that negative view of leaders in the area makes entrepreneurs feel helpless thus resulting into intolerance of corruption, nepotism and act of violence which still persist in Sub-Saharan African countries (Wanasika et al., 2011). Uncertainty avoidance results hold that an increase of uncertainties hinders the entrepreneurs' exploitation of new venture activities.

Theoretically, the study aim is to add an insight into theories that have been developed mostly in developed economies by reflecting on Tanzania's new venture context. By looking at the theory of both entrepreneurship and culture, the relationship of them demands to work with both meaning and economic change, and the way disciplinary divisions have progressed, few researchers are capable of handling both categories together (Berger, 1991). Based on our study, there is contribution to the culture knowledge in developing economies and its influence on entrepreneurs' opportunity exploitation of new venture. This study has expanded the theory which suggests that, the society to generate entrepreneurs who are ready to exploit opportunities depends on the culture foundations (Lee and Peterson, 2000, Kreiser et al., 2001).The theoretical contribution compared to other scholars was as follows:

First, our study measured the culture of individualism which provides the positive association with entrepreneurs' exploitation of new venture activities. This result is against that of (Jenssen and Kristiansen, 2004) which suggested that group cohesion has a significant effect 
on entrepreneurs' opportunities exploitation of new activities such as resources accessibility.

Second, our study results of culture of uncertainty avoidance aligned with the study by. Carson et al., (2014) that the entrepreneurs in uncertain environment should be flexible in their decisions. Thus it has added to the body of knowledge that is, the increment of the culture of uncertainty avoidance threatens the entrepreneurs on opportunity exploitation of new venture activities. Although Carson's study based on only behaviour, our study extended the idea to the exploitation of new venture activities.

Third, our study results on power distance were expected. This is due to the fact that the area where data were collected is still affected with negative view of leaders. As the study by (Wanasika et al., 2011) suggested, negative view of leaders makes entrepreneurs feel helpless something which results into tolerance of corruption, nepotism and acts of violence the behaviour which persist in Sub-Saharan African countries. The lack of significant motive in power distance to influence opportunity exploitation of new venture activities is consistent with that by(D. Carson et al., 2014) and (Zhao et al., 2012).In addition to these results, if entrepreneurs belong to the group which possesses low power (less influential), they are facing some difficulty in attaining resources for their ventures' progress. However, our study lacks the literature from the area where we investigated the phenomena being discussed.

Lastly, based on this study, we decided to find out how culture through entrepreneur proactive behaviour can influence entrepreneurs' decision on opportunity exploitation in Tanzania. We argue against other studies which assumed that Africa shares one culture (Oppong, 2013). This is due to the fact that there is a big transition going on (OECD, 2007).Culture in Africa has changed and therefore the new dimension of culture in every country is needed. Therefore we treated Tanzania as a country with heterogeneous culture whose influence on entrepreneurship might differ from those in other studies which assessed multinational cultures. The situation in every country or region has unique characteristics that no model can account for (Hofstede, 1993). By this we were able to use cultural dimension at individual level developed by (Yoo et al., 2011, Sharma, 2010) to measure the influence of culture in entrepreneurs' opportunity exploitation decision in one society (country). Although there is no study which empirically investigated the influence of culture using CVSCALE measurements in Tanzania, there are studies which used the mentioned dimensional scale to assess culture in their countries (Mazanec et al., 2015, Prasongsukarn, 2009, Yoo et al., 2011).

\subsection{Practical Implication Limitations and Future Research}

First, the generalization of culture; this study offers practical guidance to investors who are looking forward to merging or partnering which entrepreneurs in the country to know the level of culture differences and how it changes considering for example, the Chinese and other entrepreneur immigrants in the area. It should be known that African culture varies. Tanzania itself owns 120 ethnic groups which speak 120 languages (Mashenene et al., 2014) but they are connected with one national language. This means that without such a unifying language there would be chaos the root of which could start from ethnic groups. It has been observed that when entrepreneurs (especially Chinese) decide to start their venture by moving from west to east part of Africa have a tendency to simply shift with the same perception 
that they are going to handle culture differences because they have already been in Africa. In Hofstede's model for example, East Africa which has over 4 countries was given the same score. Our empirical study has shown its own results on how the of culture of individualism, power distance and uncertainty avoidance is perceived by entrepreneurs in Tanzania and made the contribution on which one is more influential in Tanzania entrepreneurs in exploiting new venture activities.

Second, the country constraints status on entrepreneurs; Tanzania is the less developed country which ventures' internal environment is experiencing inadequate training, lack of a proper business plan and capital constraints. The same situation is experienced by the external environment where there is a lack of government policy implementation and corruption (Nkonoki, 2010). It has been the country with an ambition to prosper on the economy, social and political reform for the purpose of improving the business environment, increase economic growth and reduce poverty. It is the effort which has shown the positive but very slow impact. It is one of the most quickly growing of its population which has made new entrants of labour force per years to be 600,000 to 700,000 annually which the country only accommodates 300,000 labour forces per year. Therefore, the remaining population which is almost 50\% pursue other means of earning income such as entrepreneurship and small businesses (Mfaume and Leonard, 2004).

Third, the position of entrepreneurs; as the majority entrepreneurs in developing countries such as Tanzania operate in informal economy and contribute to the Gross Domestic Product (Eijdenberg and Eijdenberg, 2016). Citizens are ready to pursue their dream through entrepreneurship by exploiting new venture activities. The citizens have no other option than pursuing entrepreneurship. It is the country which a number of necessity entrepreneurs surpass the number of opportunity entrepreneurs. We expected and we found the view of culture and reaction to it to differ from opportunity based entrepreneur to those who are need-based entrepreneurs. The culture foundation built by the country can be the leading point for entrepreneurs to positively react on opportunities. Therefore it is the duty of the policy makers to act upon the view of entrepreneurs and decide more conducive environment for them to consider opportunity exploitation of new ventures which at the end contribute to the economy.

However, although this study provided the crucial findings regarding the culture and operative mechanism of culture, the extension of the study needed to get further understanding of culture on entrepreneurs especially at society level. The study was able to cover only three dimensions of culture due to data unavailability. The study aimed to use SEM which is more appropriate method compared to regression based methods. It is the method which allows multiple relationships such as mediation to be examined simultaneously. Consideration of time and method preferred for the study ended up with only a few items to investigate, something which gives room for future research to investigate these phenomena in detail.

The study used only one mediation variable, which future researchers can study other entrepreneur behaviours such as risk taking and innovativeness as mediators to explain more 
of the observed behaviour of entrepreneurs and their decision on opportunity exploitation. However, the cross sectional study design adopted in this study provided a single snapshot of the causal relationship between culture, proactive behaviour (mediator) and entrepreneur' opportunity exploitation decision. Some theoretical view recommends that a longitudinal design would be perfect in discovering the progressive effect of characteristics such as culture and entrepreneurs proactive behaviour. Lastly, the results should not be generalized as whole country results, because this study used data from only four cities of Tanzania.

\section{References}

Abraham, R. (1997). The relationship of vertical and horizontal individualism and collectivism to intrapreneurship and organizational commitment. Leadership \& Organization Development Journal, 18, 179-186. https://doi.org/10.1108/01437739710182278

Adebayo, K., Akinmosin, A., Yussuf, S. \& Dada, A. (2011). Towards promoting micro-enterprises with ICT: An assessment of the current ICT usage level. Information Technology for People-Centred Development (ITePED 2011), Nigeria Computer Society (NCS): 10th International Conference, University of Ibadan, Nigeria, 2011.

Altinay, L. \& Wang, C. L. (2011). The influence of an entrepreneur's socio-cultural characteristics on the entrepreneurial orientation of small firms. Journal of Small Business and Enterprise Development, 18, 673-694. https://doi.org/10.1108/14626001111179749

Baron, R. A., \& Markman, G. D. (2000). Beyond social capital: How social skills can enhance entrepreneurs' success. The academy of management executive, 14, 106-116. https://doi.org/10.5465/ame.2000.2909843

Bateman, T. S., \& Crant, J. M. (1993). The proactive component of organizational behavior: A measure and correlates. Journal of organizational behavior, 14, 103-118. https://doi.org/10.1002/job.4030140202

Baughn, C. C., \& Neupert, K. E. (2003). Culture and national conditions facilitating entrepreneurial start-ups. Journal of International Entrepreneurship, 1, 313-330. https://doi.org/10.1023/A:1024166923988

Berger, B. (1991). The Culture of Entrepreneurship Book. Institute for contemporary Studies, San Francisco, California.

Bulanova, O., Shneor, J. I. J., Tiia V, R., Isaksen, E. J., \& Kolvereid, L. (2016). Growth aspirations among women entrepreneurs in high growth firms. Baltic Journal of Management, 11, 187-206. https://doi.org/10.1108/BJM-11-2014-0204

Castles, I. (1997). Review of the OECD-Eurostat PPP Program. report commissioned by the OECD. Retrieved from http://www.oecd.org.pdf

Chandler, G. N., \& Hanks, S. H. (1993). Measuring the performance of emerging businesses: A validation study. Journal of Business Venturing, 8, 391-408. https://doi.org/10.1016/0883-9026(93)90021-V 
Chang, W. L., Liu, W. G. H., \& Chiang, S. M. (2012). A Study of the Relationship between Entrepreneurship Courses and Opportunity Identification: An Empirical Survey. Asia Pacific Management Review.

Clark, A. M. (1998). The qualitative-quantitative debate: moving from positivism and confrontation to post-positivism and reconciliation. Journal of advanced nursing, 27, 1242-1249. https://doi.org/10.1046/j.1365-2648.1998.00651.x

Clydesdale, G. (2010). Entrepreneurial Opportunity. Entrepreneurial opportunity book.

Contiua, L. C., Gaborb, M. R., \& Stefanescuc, D. (2012). Hofstede's Cultural Dimensions and Student's Ability to Develop an Entrepreneurial Spirit. Procedia - Social and Behavioral Sciences, 46, 5553-5557. https://doi.org/10.1016/j.sbspro.2012.06.474

Corbett (2005). Experential Learning within The Process Of Opportunity Identification And Exploitation. Entrepreneurship Theory and Practice. https://doi.org/10.1111/j.1540-6520.2005.00094.x

Corbett, A. C. (2007). Learning asymmetries and the discovery of entrepreneurial opportunities. Journal of Business Venturing, 22, 97-118. https://doi.org/10.1016/j.jbusvent.2005.10.001

Covin, J. G., \& Slevin, D. P. (1991). A Conceptual Model of Entrepreneurship As Firm Behavior. Entrepreneurship Theory and Practice. https://doi.org/10.1177/104225879101600102

Crant, J. M. (1996). The proactive personality scale as a predictor of entrepreneurial intentions. Journal of small business management, 34, 42.

Crant, J. M. (2000). Proactive behavior in organizations. Journal of management, 26, 435-462. https://doi.org/10.1177/014920630002600304

Carson, K., Baker, S. D., \& A. Lanier, P. (2014). The role of individual cultural traits and proactivity in an organizational setting. Management Research Review, 37, 348-366. https://doi.org/10.1108/MRR-12-2012-0269

Davidsson, P., \& Wiklund, J. (1997). Values, beliefs and regional variations in new firm formation rates. Journal of Economic psychology, 18, 179-199. https://doi.org/10.1016/S0167-4870(97)00004-4

De Clercq, D., Lim, D. S. K., \& Oh, C. H. (2013). Individual-Level Resources and New Business Activity: The Contingent Role of Institutional Context. Entrepreneurship Theory and Practice, 37, 303-330. https://doi.org/10.1111/j.1540-6520.2011.00470.x

Dess, G. G., \& Robinson, R. B. (1984). Measuring organizational performance in the absence of objective measures: the case of the privately-held firm and conglomerate business unit. Strategic Management Journal, 5, 265-273. https://doi.org/10.1002/smj.4250050306

Dheer, R. J., \& Lenartowicz, T. (2016). Multiculturalism and Entrepreneurial Intentions: Understanding the Mediating Role of Cognitions. Entrepreneurship Theory and Practice. 
Eijdenberg, E. L., \& Eijdenberg, E. L. (2016). Does one size fit all? A look at entrepreneurial motivation and entrepreneurial orientation in the informal economy of Tanzania. International Journal of Entrepreneurial Behavior \& Research, 22, 804-834. https://doi.org/10.1108/IJEBR-12-2015-0295

Endres, A. M., \& Woods, C. R. (2006). Modern Theories of Entrepreneurial Behavior: A Comparison and Appraisal. Small Business Economics, 26, 189-202. https://doi.org/10.1007/s11187-004-5608-7

Engelen, A., Schmidt, S. \& Buchsteiner, M. (2015). The Simultaneous Influence of National Culture and Market Turbulence on Entrepreneurial Orientation: A Nine-country Study. Journal of International Management, $\quad 21, \quad 18-30$. https://doi.org/10.1016/j.intman.2014.12.002

Ferrante, F. (2005). Revealing Entrepreneurial Talent. Small Business Economics, 25, 159-174. https://doi.org/10.1007/s11187-003-6448-6

Fortunato, M. W. P., \& Alter, T. R. (2016). Culture and entrepreneurial opportunity in highand low-entrepreneurship rural communities. Journal of Enterprising Communities: People and Places in the Global Economy, 10, 447-476. https://doi.org/10.1108/JEC-04-2015-0026

Franke, R. H., Hofstede, G., \& Bond, M. H. (1991). Cultural roots of economic performance: A research notea. Strategic management journal, 12, 165-173. https://doi.org/10.1002/smj.4250120912

FRESE, M. (2009). Towards a Psychology of Entrepreneurship: An Action Theory perspective. Foundations and Trends in Entrepreneurship, 5, 435-494. https://doi.org/10.1561/0300000028

Garcia, F., Mendez, D., Ellis, C. \& Gautney, C. (2014). Cross-cultural, values and ethics differences and similarities between the US and Asian countries. Journal of Technology Management in China, 9, 303-322. https://doi.org/10.1108/JTMC-05-2014-0025

Gardiner, K. M. (1996). Managing in different cultures: the case of Ghana. The Handbook of Human Resource Management, 2.

Gielnik, M. M., Zacher, H., \& Frese, M. (2012). Focus on opportunities as a mediator of the relationship between business owners' age and venture growth. Journal of Business Venturing, 27, 127-142. https://doi.org/10.1016/j.jbusvent.2010.05.002

Gupta, V. K., Goktan, A. B., \& Gunay, G. (2014). Gender differences in evaluation of new business opportunity: A stereotype threat perspective. Journal of Business Venturing, 29, 273-288. https://doi.org/10.1016/j.jbusvent.2013.02.002

Hansen, J. D., Deitz, G. D., Tokman, M., Marino, L. D., \& Weaver, K. M. (2011). Cross-national invariance of the entrepreneurial orientation scale. Journal of Business Venturing, 26, 61-78. https://doi.org/10.1016/j.jbusvent.2009.05.003 
Hayton, J. C., \& Cacciotti, G. (2013). Is there an entrepreneurial culture? A review of empirical research. Entrepreneurship \& Regional Development, 25, 708-731. https://doi.org/10.1080/08985626.2013.862962

Hayton, J. C., George, G., \& Zahra, S. A. (2002). National culture and entrepreneurship: A review of behavioral research. Entrepreneurship Theory and Practice, 26, 33. https://doi.org/10.1177/104225870202600403

Hellsing, M., \& Olsson, L. (2010). Experiences of female entrepreneurs in Tanzania: A cultural comparacy between individualism and collectivism.

Hofstede. (1980). Dimension of culture.

Hofstede, G. (1984). Culture's consequences: International differences in work-related values. sage.

Hofstede, G. (1993). Cultural constraints in management theories Hofstede.pdf $>$. Academy of Management Executive, 7, 81.

Hofstede, G. H., \& Hofstede, G. (2001). Culture's consequences: Comparing values, behaviors, institutions and organizations across nations. Sage.

House, R., Javidan, M., Hanges, P., \& Dorfman, P. (2002). Understanding cultures and implicit leadership theories across the globe: an introduction to project GLOBE. Journal of World Business, 37, 3-10. https://doi.org/10.1016/S1090-9516(01)00069-4

Hoyle, R. H. (2012). Handbook_of_Structural_Equation_Modeling. The Guilford Press.

Jenssen, J. I., \& Kristiansen, S. (2004). Sub-cultures and entrepreneurship: The value of social capital in Tanzanian business. Journal of Entrepreneurship, 13, 1-27. https://doi.org/10.1177/097135570401300101

Jr, J. H., Black, W. C., Babin, B. J., \& Anderson, R. E. (2009). Multivariate Data Analysis (7th ed.).

Katundu, M. A., \& Gabagambi, D. M. (2014). Determinants of Entrepreneurial Tendencies among Tanzanian University Graduates: A Case of University of Dar-es-Salaam. European academic research, 2, 835-869.

Kline, R. B. (2011). Principal of Practice and Structural Equation Modeling (3rd ed.).

Kollmann, T., Christofor, J., \& Kuckertz, A. (2007). Explaining individual entrepreneurial orientation: Conceptualisation of a cross-cultural research framework. International Journal of Entrepreneurship and Small Business, 4, 340. ttps://doi.org/10.1504/IJESB.2007.013255

Kragh, S. U. (2016). Tribe and village in African organizations and business. Personnel Review, 45, 51-66. https://doi.org/10.1108/PR-08-2012-0140 
Kreiser, P., Marino, L., \& Weaver, K. M. (2001). Correlates of entrepreneurship: The impact of national culture on risk-taking and proactiveness in SMEs. University of Alabama, Department of Management and Marketing.

Kreiser, P. M., Louis D, M., Dickson, P., \& Weaver, K. M. (2010a). Cultural Influences on Entrepreneurial Orientation: The Impact of National Culture on Risk Taking And Proactiveness in Smes. Entrepreneurship Theory and Practice. https://doi.org/10.1111/j.1540-6520.2010.00396.x

Kreiser, P. M., Marino, L. D., Dickson, P., \& Weaver, K. M. (2010b). Cultural influences on entrepreneurial orientation: The impact of national culture on risk taking and proactiveness in SMEs. Entrepreneurship Theory and Practice, 34, 959-983. https://doi.org/10.1111/j.1540-6520.2010.00396.x

Langkamp Bolton, D. \& Lane, M. D. (2012). Individual entrepreneurial orientation: development of a measurement instrument. Education + Training, 54, 219-233. https://doi.org/10.1108/00400911211210314

Lee, S. M., \& Peterson, S. J. (2000). Culture, entrepreneurial orientation, and global competitiveness. Journal of World Business, 35, 401-416. https://doi.org/10.1016/S1090-9516(00)00045-6

Lumpkin, G. T., \& Dess, G. G. (1996a). Clarifying the entrepreneurial orientation construct and linking it to performance. Academy of management Review, 21, 135-172. https://doi.org/10.5465/amr.1996.9602161568

Lumpkin, G. T., \& Dess, G. G. (1996b). Clarifying The Entrepreneurial Orientation Construct And Linking It To Performance-Suggested. Academy of Management Review, 21, 135-172. https://doi.org/10.5465/amr.1996.9602161568

Luo, Y., \& Junkunc, M. (2008). How private enterprises respond to government bureaucracy in emerging economies: The effects of entrepreneurial type and governance. Strategic Entrepreneurship Journal, 2, 133-153. https://doi.org/10.1002/sej.46

Mackinnon, D. P., Lockwood, C. M., \& Williams, J. (2004). Confidence limits for the indirect effect: Distribution of the product and resampling methods. Multivariate behavioral research, 39, 99-128. https://doi.org/10.1207/s15327906mbr3901_4

Marino, L., Strandholm, K., Steensma, H. K. \& Weaver, K. M. (2002). The moderating effect of national culture on the relationship between entrepreneurial orientation and strategic alliance portfolio extensiveness. Entrepreneurship: Theory and Practice, 26, 145-161. https://doi.org/10.1177/104225870202600409

Mashenene, R. G., Lyimo, J. G., \& Donge, L. (2014). Sociocultural Determinants of Entrepreneurial Capabilities among The Chaga and Sukuma Small And Medium Entreprises in Tanzania. Journal of Economics and Sustainable Development, 5.

Mazanec, J. A., Crotts, J. C., Gursoy, D., \& Lu, L. (2015). Homogeneity versus heterogeneity of cultural values: An item-response theoretical approach applying Hofstede's cultural 
dimensions in a single nation. Tourism Management, 48, 299-304. https://doi.org/10.1016/j.tourman.2014.11.011

Mcgrath, R. G., \& Macmillan, I. C. (2000). The entrepreneurial mindset: Strategies for continuously creating opportunity in an age of uncertainty, Harvard Business Press.

Mcgrath, R. G., Macmillan, I. C., \& Scheinberg, S. (1992). Elitists, risk-takers, and rugged individualists? An exploratory analysis of cultural differences between entrepreneurs and non-entrepreneurs. Journal of business venturing, 7, 115-135. https://doi.org/10.1016/0883-9026(92)90008-F

Mfaume, R. M., \& Leonard, W. (2004). Small business entrepreneurship in Dar es Salaam-Tanzania: Exploring problems and prospects for future development. African Development and Poverty Reduction, Somerset West, South Africa.

Mihet, R. 2012. <Effects on Culture on Firm Risk-Taking: A cross-country and Cross-Industry Analysis.pdf $>$. international Monetary Fund(IMF) Working paper.

Mitchell, R. K., Smith, B., Seawright, K. W., \& Morse, E. A. 2000. Cross-cultural cognitions and the venture creation decision. Academy of management Journal, 43, 974-993.

Mkasanga, E. A. (2015). Cultural dimensions and perfomance of women's entrepreneurial initiatives: a case of Mvomero district, Tanzania. Sokoine University of Agriculture.

Mueller, S. L., \& Thomas, A. S. (2001). Culture and Entrepreneurial Potential- A Nine Country Study of Locus Of Control And Innovativeness. Journal of Business Venturing, 16, 51-75. https://doi.org/10.1016/S0883-9026(99)00039-7

Mwasalwiba, E., Dahles, H., \& Wakkee (2012). Graduate Entrepreneurs in Tanzania: Contextual Enablers and Hindrances. European Journal of Scientific Research, 76, 386-402.

Naudé, W. (2013). Entrepreneurship and economic development: Theory, evidence and policy. Browser Download This Paper.

Naudé, W., Szirmai, A., \& Goedhuys, M. (2011). Innovation and entrepreneurship in developing countries. UNU.

Nkonoki, E. (2010). Factors Limiting the Success \& Growth of Small Busineses in TanzaniaAn Empirical Study. Arcada University of Applied Science.

Nyambegera, S. M. (2002). Ethnicity and human resource management practice in sub-Saharan Africa: the relevance of the managing diversity discourse. International Journal of Human Resource Management, 13, 1077-1090. https://doi.org/10.1080/09585190210131302

OECD. (2007). OECD thematic review of tertiary education.

Oppong, N. Y. (2013). Towards African Work Orientations: Guide from Hofstede's Cultural Dimensions. European Journal of Business And Management, 5. 
Pallant, J. (2007). SPSS Survival Manual: A Step tp Step guide data analysis using SPSS for windows. Philadephia, Open University Press.

Prandelli, E., Pasquini, M. \& Verona, G. (2016). In user's shoes: An experimental design on the role of perspective taking in discovering entrepreneurial opportunities. Journal of Business Venturing, 31, 287-301. https://doi.org/10.1016/j.jbusvent.2016.02.001

Prasongsukarn, K. (2009). Validating the cultural value scale (CVSCALE): a case study of Thailand. ABAC journal, 29.

Riquelme, H. E. (2013). In Search of Entrepreneurial Opportunities — an Integrated Model. Journal of Enterprising Culture, 21, 249-274. https://doi.org/10.1142/S0218495813500118

Schumpeter, J. (1934a). The Theory of Economic Development (translated by Redvers Opie) Harvard University Press. Cambridge, $M A$.

Schumpeter, J. A. (1934b). The theory of economic development: An inquiry into profits, capital, credit, interest, and the business cycle. Transaction publishers.

Shane, S. (1993). Cultural influences on national rates of innovation. Journal of Business Venturing, 8, 59-73. https://doi.org/10.1016/0883-9026(93)90011-S

Shane, S. (1995). Uncertainty avoidance and the preference for innovation championing roles. Journal of International Business 47-68. https://doi.org/10.1057/palgrave.jibs.8490165

Sharma, P. (2010). Measuring personal cultural orientations: scale development and validation. Journal of the Academy of Marketing Science, 38, 787-806. https://doi.org/10.1007/s11747-009-0184-7

Simsek, Z. (2007). CEO tenure and organizational performance: An intervening model. Strategic Management Journal, 28, 653-662. https://doi.org/10.1002/smj.599

Simsek, Z., \& Heavey, C. (2011). The Mediating role of Knowledge Based capital for corporate entrepreneurship effect on performance: A study of small to medium sized firms. Strategic Entrepreneurship Journal, 81-100. https://doi.org/10.1002/sej.108

Stephan, U., \& Pathak, S. (2016). Beyond cultural values? Cultural leadership ideals and entrepreneurship. Journal of Business Venturing, 31, 505-523. https://doi.org/10.1016/j.jbusvent.2016.07.003

Swartz, E., \& Davies, R. (1997). Ubuntu-the spirit of African transformation management-a review. Leadership \& Organization Development Journal, 18, 290-294. https://doi.org/10.1108/01437739710176239

Taatila, V., Matlay, H., \& Down, S. (2012). Measuring entrepreneurial orientation of $\begin{array}{llll}\text { university } \quad \text { students. } & \text { Education }+ & \text { Training, } & \text { 54, }\end{array}$ https://doi.org/10.1108/00400911211274864 
Tang, J. (2008). Environmental munificence for entrepreneurs: entrepreneurial alertness and commitment. International Journal of Entrepreneurial Behavior \& Research, 14, 128-151. https://doi.org/10.1108/13552550810874664

Thompson, J. D. (1967). Organizations in action: Social science bases of administrative theory, Transaction publishers.

Thornton, P. H., Ribeiro-Soriano, D., \& Urbano, D. (2011). Socio-cultural factors and entrepreneurial activity: An overview. International Small Business Journal, 29, 105-118. https://doi.org/10.1177/0266242610391930

Tiessen, J. H. 1997. Individualism, collectivism, and entrepreneurship: A framework for international comparative research. Journal of Business Venturing, 12, 367-384. https://doi.org/10.1016/S0883-9026(97)81199-8

Tocher, N., Oswald, S. L., \& Hall, D. J. (2015). Proposing social resources as the fundamental catalyst toward opportunity creation. Strategic Entrepreneurship Journal, 9, 119-135. https://doi.org/10.1002/sej.1195

Valliere, D. (2014). Culture, values and entrepreneurial motivation in Bhutan. Journal of Enterprising Communities: People and Places in the Global Economy, 8, 126-146. https://doi.org/10.1108/JEC-02-2013-0002

Wanasika, I., Howell, J. P., Littrell, R., \& Dorfman, P. (2011). Managerial leadership and culture in Sub-Saharan Africa. Journal of World Business, 46, 234-241. https://doi.org/10.1016/j.jwb.2010.11.004

Wood, M. S., Bylund, P., \& Bradley, S. (2016). The influence of tax and regulatory policies on entrepreneurs' opportunity evaluation decisions. Management Decision, 54, 1160-1182. https://doi.org/10.1108/MD-10-2015-0446

Wood, M. S., Mckelvie, A. \& Haynie, J. M. 2014. Making it personal: Opportunity individuation and the shaping of opportunity beliefs. Journal of Business Venturing, 29, 252-272. https://doi.org/10.1016/j.jbusvent.2013.02.001

Yeboah, M. A. (2014). How Does Culture Influence Risk-Takin In Smes In The Sekondi-Tarakoradi Metropolis Ghana. American Internationa Journal of Contemporary research, 4, No 2

Yoo, B., Donthu, N., \& Lenartowicz, T. (2011). Measuring Hofstede's five dimensions of cultural values at the individual level: Development and validation of CVSCALE. Journal of International Consumer Marketing, 23, 193-210.

Zahra, S. A. (1996). Goverance, ownership, and corporate entrepreneurship: The moderating impact of industry technological opportunities. Academy of Management Journal, 39, 1713-1735. https://doi.org/10.5465/257076

Zahra, S. A. (1999). The changing rules of global competitiveness in the 21 st century. The Academy of Management Executive, 13, 36-42. https://doi.org/10.5465/ame.1999.1567300 


\section{Macrothink}

International Journal of Regional Development ISSN 2373-9851

Zhao, X., Li, H., \& Rauch, A. (2012). Cross-country differences in entrepreneurial activity: The role of cultural practice and national wealth. Frontiers of Business Research in China, 6, 447-474.

\section{Copyright Disclaimer}

Copyright for this article is retained by the author(s), with first publication rights granted to the journal.

This is an open-access article distributed under the terms and conditions of the Creative Commons Attribution license (http://creativecommons.org/licenses/by/3.0/). 